\title{
PENGARUH CAHAYA LAMPU TERHADAP POLA AGREGASI IKAN DI BAGAN TANCAP PERAIRAN KEPULAUAN SERIBU
}

\author{
Asep Priatna dan Mahiswara \\ Peneliti pada Balai Riset Perikanan Laut, Muara Baru-Jakarta \\ Teregistrasi I tanggal: 6 Agustus 2008; Diterima setelah perbaikan tanggal: 2 Maret 2009; \\ Disetujui terbit tanggal: 13 April 2009
}

\begin{abstract}
ABSTRAK
Penelitian ini bertujuan untuk mempelajari pola agregasi ikan di bawah pengaruh cahaya lampu bagan tancap. Penelitian dilaksanakan pada bulan Mei 2005 di Kepulauan Seribu. Pengamatan pola agregasi ikan dilakukan dengan menggunakan alat akustik Simrad EY500. Data intensitas cahaya diambil dengan menggunakan light meter LI-250, serta verifikasi hasil tangkapan untuk memperkuat hasil analisis. Analisis meliputi interpretasi visual berbasis pada presentasi grafik yang merupakan dasar bagi penafsiran data dan penyusunan informasi. Pengaruh intensitas cahaya yang berbeda terhadap agregasi ikan mempunyai pola yang tidak sama, baik nilai intensitas cahaya optimumnya, besarnya agregasi, maupun posisi kedalaman untuk nilai agregasi terbesar. Proses pengumpulan ikan pada awal penyinaran dengan perlakuan jenis lampu petromak lebih cepat dibanding dengan hasil perlakuan lampu mercuri. Ikan akan beradaptasi terhadap variasi iluminasi cahaya sehingga selama proses pencahayaan terjadi migrasi.
\end{abstract}

KATAKUNCI: akustik, bagan tancap, agregasi ikan, intensitas cahaya

ABSTRACT: The influence of light intensity on fish aggregation around stationary bamboo lift net in Seribu Islands waters. By: Asep Priatna and Mahiswara

The research objective was to study fish aggregation pattern under light influence set in stationary bamboo lift net. This research was conducted on May 2005 in Seribu Islands waters. Simrad EY-500 echosounder was used to observe the fish aggregation. Light meter LI-250 was used to measure light intensity level and catch data for supporting the analysis result. Data analyzed by visual description based on graph presentation were used as data interpretation and information. The influence of different light intensity on fish aggregation had different pattern especially for optimum value of light intensity, maximum value of fish aggregation, and depth layer of the maximum value of fish aggregation. For fish aggregation under light of kerosene pressured lamps was quicker than mercury lamps in the early of illumination process. Fish will adapt to various light illumination, so that during illumination process the migration of fish is occured.

\section{KEYWORDS: acoustic, stationary bamboo lift net, fish aggregation, light intensity}

\section{PENDAHULUAN}

Penelitian pengaruh intensitas cahaya buatan terhadap tingkah laku ikan pelagis kecil tropis sangat sedikit dan terbatas, bahkan penelitian intensitas cahaya optimal dalam agregasi kelompok ikan tersebut belum pernah dilakukan.

Levenez et al. (1990) menggunakan echosounder dan digital echo integrator untuk mengamati reaksi dari jenis ikan pelagis terhadap cahaya lampu. Baskoro (1999) mendeteksi keberadaan kelompok ikan yang tertarik dengan cahaya lampu di bagan apung dengan menggunakan echosounderdan sonar.

Cahaya merupakan bagian fundamental dalam menentukan tingkah laku ikan di laut (Woodhead, 1966). Stimuli cahaya terhadap tingkah laku ikan sangat kompleks antara lain intensitas, sudut penyebaran, polarisasi, komposisi spektralnya, dan lama penyinaran. Cahaya, baik itu durasi maupun intensitasnya, memainkan peran yang sangat penting dalam kehidupan ikan di mana terjadi beberapa reaksi dasar dari ikan terhadap cahaya yang menjadi perhitungan ketika menjaga sumber daya ikan dalam suatu ekosistem (Delbeek, 1986).

Nelayan beranggapan bahwa semakin tinggi intensitas cahaya yang digunakan, semakin besar kelompok ikan yang dapat dikumpulkan. Oleh karena itu, pada perikanan bagan terdapat variasi penggunaan jenis lampu mulai dari lampu petromak sampai lampu fluorocent.

Beberapa peralatan yang dapat digunakan untuk memahami proses penangkapan telah dijelaskan oleh Arimoto et al. (1999) seperti video kamera, sonar, dan biotelemetri. Penerapan metode akustik melalui 


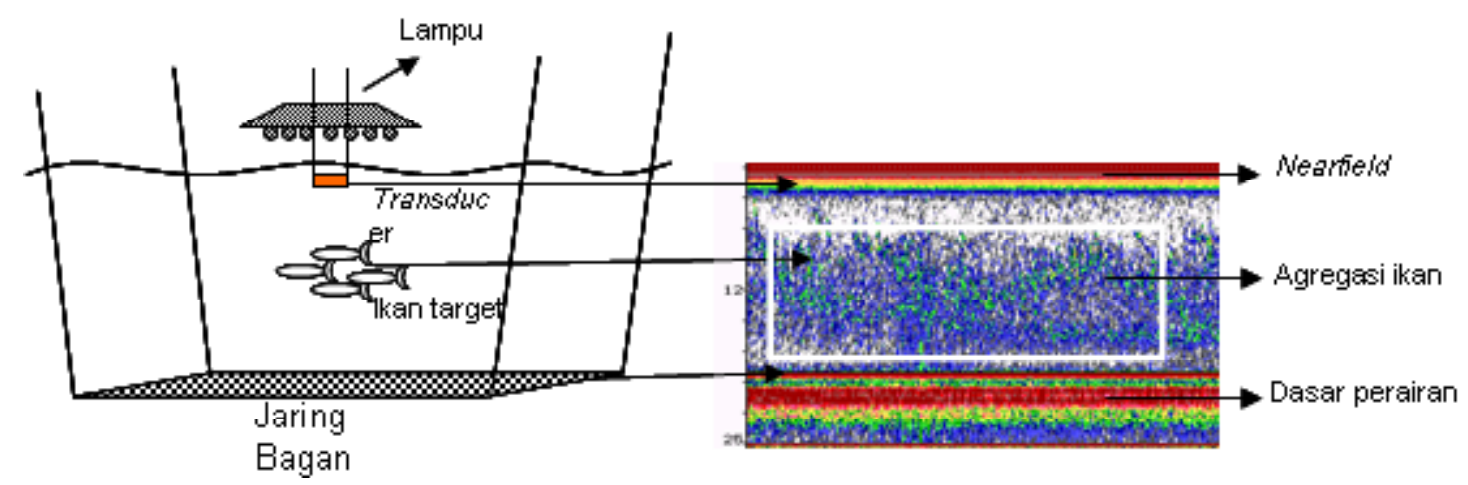

Gambar 1. Ilustrasi pengambilan contoh pada waktu akuisisi data akustik.

Figure 1. Ilustration of stationary sampling at acoustic data acquisition.

peralatan sonar atau echosounder dapat digunakan antara lain untuk studi tingkah laku ikan, kecepatan renang, dan respons ikan terhadap stimuli. Tujuan dari penelitian ini adalah untuk mengetahui pola agregasi ikan di bawah pengaruh cahaya lampu pada intensitas yang berbeda dengan metode akustik.

\section{BAHAN DAN METODE}

Penelitian dilakukan pada bagan tancap yang berlokasi di perairan Pulau Lancang, Kepulauan Seribu selama 2 hari, yaitu dari tanggal 14-15 Mei 2005. Pengamatan dilakukan dengan metode tetap (stationary sampling), posisi transducer dipasang di atas jaring bagan tepat di bawah pusat cahaya lampu.

\section{Pengambilan Data}

Akuisisi data akustik (Gambar 1) menggunakan echosounder SIMRAD EY500 yang berfrekuensi 38 $\mathrm{kHz}$. Perekaman data untuk perlakuan 5 dan 10 lampu petromak dilakukan pada hari pertama sementara perlakuan dengan 250, 500, dan 1.000 watt lampu mercury pada hari kedua. Rata-rata lamanya penyinaran adalah 3 jam pada tiap perlakuan. Pengaturan parameter sistem akustik adalah sama untuk setiap perlakuan yaitu target strength threshold $-70 \mathrm{~dB}$ dan SV threshold $-80 \mathrm{~dB}$. Data intensitas cahaya diambil di bawah pusat cahaya pada setiap kedalaman $1 \mathrm{~m}$ dengan menggunakan Light Meter model LI-250. Pengambilan contoh dilakukan pada awal periode penyinaran tiap perlakuan. Data hasil tangkapan diperoleh dari setiap haulling pada masingmasing perlakuan penyinaran.

\section{Pengolahan dan Analisis Data}

Indeks kepadatan ikan selama proses perlakuan penyinaran oleh sumber cahaya yang berbeda digambarkan berdasarkan pada reverberasi akustik yang dikatakan dalam nilai integrasi area back scattering strength $\left(\mathrm{s}_{\mathrm{A}}\right)$ dalam satuan $\mathrm{m}^{2} / \mathrm{nmi}^{2}$, sedangkan indikator ukuran ikan digambarkan berdasarkan pada nilai target strength (Arnaya, 1991). Pengolahan data akustik tiap strata $1 \mathrm{~m}$, selanjutnya dibagi ke dalam wilayah cahaya (light zone); yaitu kolom perairan yang mendapatkan intensitas cahaya serta wilayah gelap (dark zone). Hasil ditampilkan dalam bentuk grafik sebaran nilai $\mathrm{s}_{\mathrm{A}}$ dan target strength terhadap waktu pengamatan setiap ESDU 5 menit dari berbagai perlakuan penyinaran, pembagian elementary sampling distance unit bertujuan untuk mempermudah dalam pembahasan. Analisis meliputi interpretasi visual berbasis pada presentasi grafikal yang merupakan dasar bagi penafsiran data dan penyusunan informasi. Interpretasi meliputi variasi intensitas cahaya dan lama penyinaran terhadap agregasi ikan, distribusi spasio-temporal kepadatan dan ukuran ikan untuk masing-masing penyinaran, dan komposisi hasil tangkapan untuk verifikasi data akustik.

\section{HASIL DAN BAHASAN}

\section{Pengaruh Intensitas Cahaya terhadap Agregasi Ikan}

Berdasarkan pada hasil pengamatan di wilayah cahaya, pada perlakuan penyinaran dengan 5 buah lampu petromak nilai, maksimum rata-rata $\mathrm{s}_{\mathrm{A}}$ adalah $2,8 \mathrm{~m}^{2} / \mathrm{nmi}^{2}$ pada kedalaman sekitar $5 \mathrm{~m}$ dengan intensitas cahaya $0,042 \mu \mathrm{mol} \mathrm{s}-1 \mathrm{~m}-2$. Hasil perlakuan penyinaran dengan 10 buah lampu petromak, menunjukkan bahwa nilai maksimum rata-rata $\mathrm{s}_{\mathrm{A}}$ adalah $10 \mathrm{~m}^{2} / \mathrm{nmi}^{2}$, yaitu di sekitar permukaan yang dekat dengan sumber cahaya dengan intensitas 1,464 umol s-1 m-2 (Gambar 2).

Pada perlakuan penyinaran 250 watt lampu mercury, nilai maksimum rata-rata $\mathrm{s}_{\mathrm{A}}$ adalah $3 \mathrm{~m}^{2} /$ 
$\mathrm{nmi}^{2}$ yang diperoleh pada kedalaman sekitar $2 \mathrm{~m}$ dengan intensitas cahaya 0,712 $\mu \mathrm{mol} \mathrm{s}-1 \mathrm{~m}-2$. Nilai maksimum rata-rata $s_{A}$ untuk penyinaran 500 watt lampu mercury adalah1,6 $\mathrm{m}^{2} / \mathrm{nmi}^{2}$, yaitu pada kedalaman $5 \mathrm{~m}$ dengan intensitas cahaya 0,226 $\mu \mathrm{mol}$ s-1 m-2 (Gambar 3).

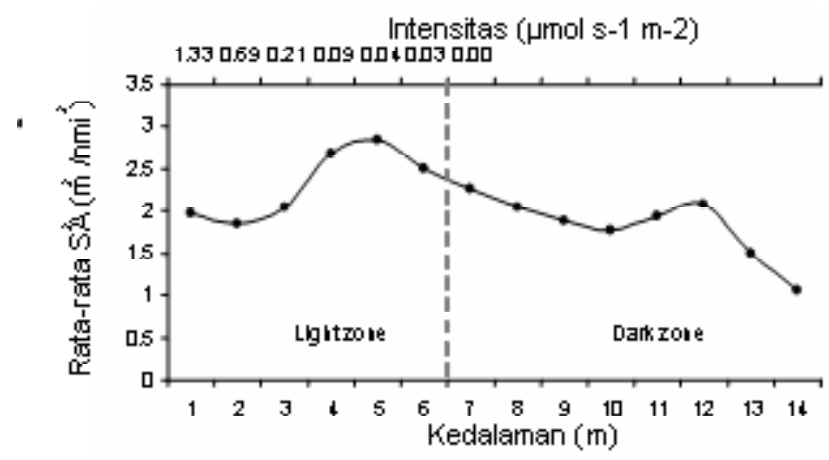

Gambar 4 menunjukkan bahwa pada penyinaran 1.000 watt lampu mercury, nilai intensitas cahaya optimal teramati pada lapisan permukaan dengan nilai $4,342 \mu \mathrm{mol}$ s-1 m-2. Nilai maksimum rata-rata $\mathrm{s}_{\mathrm{A}}$ yaitu $1,6 \mathrm{~m}^{2} / \mathrm{nmi}^{2}$.

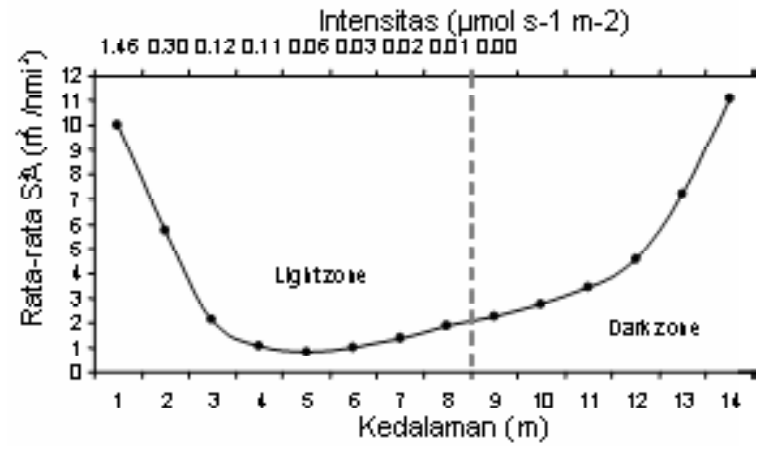

Gambar 2. Pengaruh intensitas cahaya terhadap nilai $\mathrm{s}_{\mathrm{A}}$ pada penyinaran 5 buah (kiri) dan 10 buah (kanan) lampu petromak.

Figure 2. Effect of light intensity on $s_{A}$ value at 5 (left) and 10 (right) kerosene pressured lamps.

Intensitas (umol s-1 m-2)

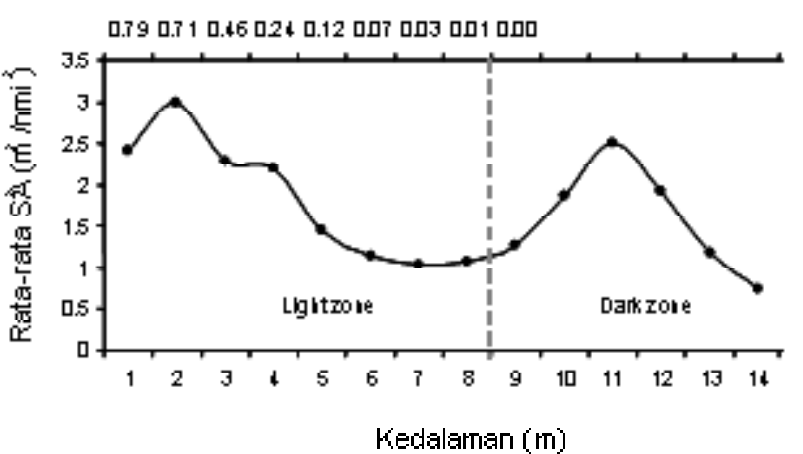

Intensitas (umol s-1 m-2)

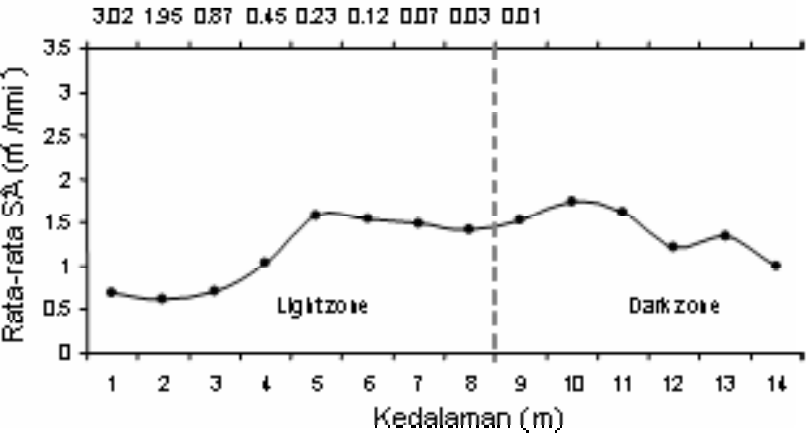

Gambar 3. Pengaruh intensitas cahaya terhadap nilai $\mathrm{s}_{\mathrm{A}}$ pada penyinaran 250 watt (kiri) dan 500 watt (kanan) lampu mercury.

Figure 3. Effect on light intensity to $s_{A}$ value at 250 watt (left) dan 500 watt (right) mercury lamp.

Intensitas (umol s-1 m-2)

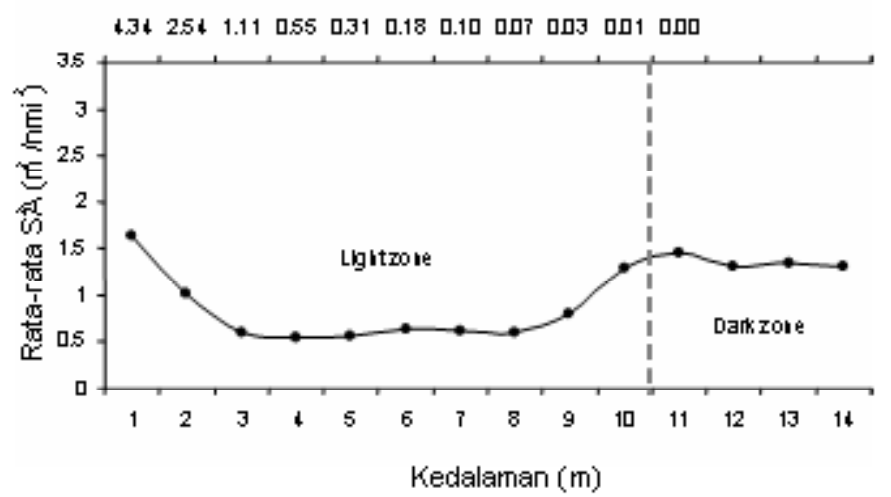

Gambar 4. Pengaruh intensitas cahaya terhadap nilai $\mathrm{s}_{\mathrm{A}}$ pada penyinaran 1.000 watt lampu mercury.

Figure 4. Effect of light intensity on $s_{A}$ value at 1,000 watt mercury lamp. 
Nilai intensitas cahaya optimum untuk agregasi ikan pada setiap perlakuan penyinaran adalah tidak sama. Nilai agregasinya yang berbeda pula. Selain itu, masing-masing agregasi ikan optimum dari setiap perlakuan ditemukan pada kedalaman yang berbeda pula. Berdasarkan pada data akustik, pengaruh berbagai intensitas cahaya terhadap agregasi ikan mempunyai pola yang tidak sama. Perbedaan tersebut tidak terlepas dari faktor fisiologi ikan yang berada pada lahan penelitian. Ikan mempunyai sejumlah adaptasi untuk variasi tingkat cahaya. Tingkah laku seperti aktivitas diurnal, jenis dan ukuran, serta interaksi mangsa dan pemangsa mempunyai hubungan yang signifikan terhadap derajat iluminasi cahaya (Nikolsky, 1963).

Hasil menunjukkan bahwa dari masing-masing perlakuan, nilai $\mathrm{s}_{\mathrm{A}}$ terbesar diperoleh pada perlakuan dengan sumber cahaya 10 lampu petromak. Agregasi maksimum ditemukan pada lapisan permukaan dengan intensitas cahaya 0,3-1,4 $\mu \mathrm{mol} \mathrm{s}-1 \mathrm{~m}-2$. Gambaran pengelompokkan ikan selama periode penyinaran dapat dilihat pada Gambar 7-11.

\section{Pengaruh Waktu Penyinaran terhadap Pola Agregasi Ikan}

Gambar 5 memperlihatkan trend perubahan nilai $\mathrm{S}_{\mathrm{A}}$ berdasarkan pada lamanya waktu penyinaran dengan 5 dan 10 petromak. Masing-masing data perlakuan dibagi 2 strata yaitu wilayah cahaya (light zone) dan wilayah gelap (dark zone). Trend agregasi pada wilayah cahaya dari kedua perlakuan tersebut menunjukkan pola yang sama, yaitu trend yang menurun dengan kemiringan yang relatif kecil. Penurunan diduga akibat predasi terhadap ikan pelagis berukuran kecil seperti ikan teri (Stelephorus indicius) yang berada di permukaan, migrasi ikan dari wilayah cahaya ke wilayah gelap karena faktor kejenuhan dari pencahayaan langsung, serta keluarnya ikan dari lahan tangkapan (catchable area). Rata-rata $\mathrm{s}_{\mathrm{A}}$ hasil perlakuan 10 petromak sekitar 2 kali lebih besar daripada rata-rata $s_{A}$ hasil perlakuan dengan 5 petromak.

Pada wilayah gelap terjadi pola peningkatan agregasi seiring pertambahan waktu penyinaran. Selain migrasi ikan dari wilayah cahaya, juga akibat penambahan jumlah ikan demersal seperti ikan petek (Leiognathus bindus) di wilayah gelap. Perubahan besar terjadi pada perlakuan dengan 10 petromak, sehingga proses peningkatan agregasi jauh lebih cepat sekitar 7 kali lipat dibanding perlakuan 5 lampu petromak.

Hasil pengambilan contoh pada 250,500 , dan 1.000 watt lampu mercury memperlihatkan pola agregasi yang sama, di mana didapatkan trend perubahan nilai $\mathrm{s}_{\mathrm{A}}$ yang cenderung meningkat, kecuali di wilayah gelap pada perlakuan 1.000 watt mercury (Gambar 6). Pola agregasi pada perlakuan 250 watt mercury menunjukkan bahwa proses pengumpulan ikan adalah yang paling cepat daripada perlakuan penyinaran yang lain. Pada wilayah cahaya, rata-rata nilai $s_{A}$ hasil perlakuan 250 watt selama periode pengambilan contoh yang paling besar yaitu sekitar 2 kali nilai $S_{A}$ hasil perlakuan 500 dan 1.000 watt lampu mercury.

Hasil perlakuan lampu petromak (Gambar 5) menunjukkan bahwa pada awal penyinaran didapatkan nilai $s_{A}$ yang lebih besar daripada hasil perlakuan lampu mercury (Gambar 6). Hal ini mengindikasikan bahwa ikan yang ada di perairan ini mempunyai respon yang lebih cepat terhadap sumber cahaya dengan iluminasi rendah. Proses pengumpulan

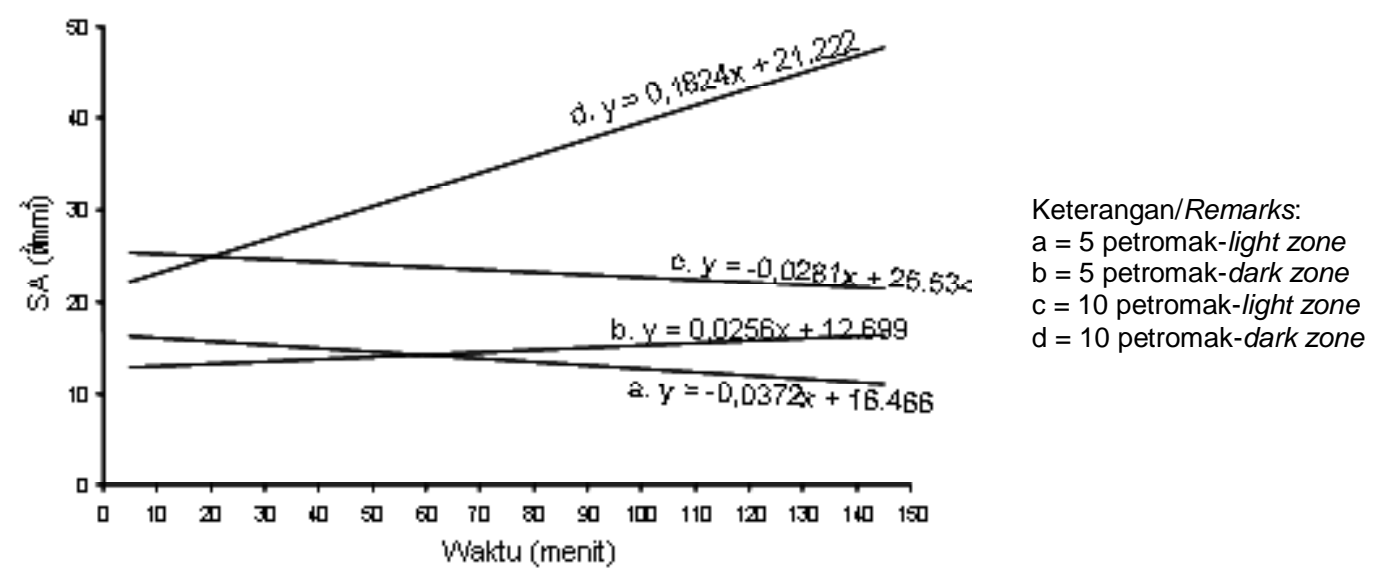

Gambar 5. Trend perubahan nilai $\mathrm{s}_{\mathrm{A}}$ selama proses penyinaran pada perlakuan 5 dan 10 buah lampu petromak.

Figure 5. Trend of $s_{A}$ value during ilumination process in 5 and 10 of kerosene pressured lamps. 


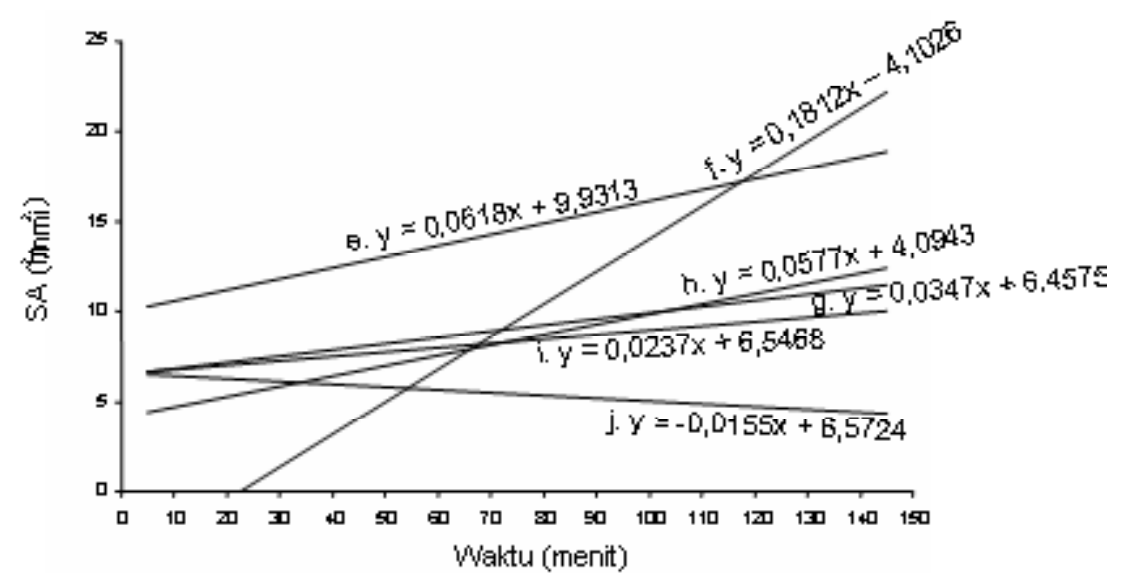

Keterangan/Remarks: $\mathrm{e}=250$ watt-light zone $\mathrm{f}=250$ watt-dark zone $\mathrm{g}=500$ watt-light zone $\mathrm{h}=500$ watt-dark zone $\mathrm{i}=1.000$ watt-light zone $=1.000$ watt-dark zone

Gambar 6. Trend perubahan nilai $\mathrm{s}_{\mathrm{A}}$ selama proses penyinaran pada perlakuan 250,500 , dan 1.000 watt lampu mercury.

Figure 6. Trend of $s_{A}$ value during ilumination process at 250, 500, and 1,000 watt mercury lamps.

ikan pada awal penyinaran dengan jenis lampu petromak lebih cepat dibanding dengan hasil lampu mercury.

Perbandingan kecepatan agregasi ikan selama periode penyinaran untuk perlakuan 5 dan 10 petromak, serta 250, 500, dan 1.000 watt mercury di wilayah cahaya berturut-turut adalah 1,6:1,2:2,6:1,5:1, sedangkan pada wilayah gelap 1,7:11,8:11,7:3,7:1 dalam satuan $\mathrm{s}_{\mathrm{A}}$ per menit. Jenis ikan yang berbeda mempunyai tingkat adaptasi yang berbeda pula untuk variasi iluminasi cahaya. Berdasarkan pada verifikasi hasil tangkapan (Gambar 13), kecepatan agregasi pada perlakuan 5 petromak, 250 dan 500 watt didominansi oleh ikan teri yang menunjukkan reaksi kuat terhadap sumber cahaya (Baskoro, 1999). Pada perlakukan 10 petromak dan 1.000 mercury, hasil tangkapan didominansi ikan yang berukuran lebih besar seperti cumi (Loligo sp.), ikan selar (Selaroides crumenopthalmus), tembang (Sardinella fimbriata), bentong (Selar crumenophtalmus), dan hanya sedikit didapatkan ikan teri. Diduga ikan dengan ukuran lebih besar mempunyai respon cahaya yang lebih lambat dibanding ikan dengan ukuran lebih kecil, sehingga laju agregasi pada perlakukan tersebut cenderung lambat.

\section{Spasio-Temporal Kepadatan dan Ukuran Ikan}

Pola agregasi ikan dari perlakuan 5 lampu petromak dapat dilihat pada Gambar 7. Kelompok ikan hasil perlakuan ini didominansi oleh ikan teri yang mencapai $80 \%$ hasil tangkapan (Gambar 13). Menurut Sulaiman (2006), pola distribusi kawanan ikan teri berada dipermukaan dekat sumber pencahayaan. Gerombolan ikan dengan ukuran relatif kecil cenderung bergerak ke kolom perairan yang lebih dalam dengan konsentrasi yang semakin rendah seiring dengan lamanya penyinaran. Kelompok ini juga dihuni oleh ikan dengan ukuran yang lebih besar, tapi dengan konsentrasi yang lebih sedikit, dibandingkan jenis ikan teri. Jenis ikan tersebut diduga terdiri atas ikan tembang, selar, bentong, selar kuning (Selaroides leptolepis), dan cumi-cumi. Terdapat kelompok ikan demersal seperti jenis ikan petek dengan konsentrasi rendah yang cenderung diam di dekat dasar perairan.

Gambar 8 menunjukkan pola agregasi ikan pada perlakuan 10 lampu petromak. Ikan yang terdeteksi sebagian besar terpisah menjadi 2 kelompok, yaitu kelompok ikan yang cenderung berada di lapisan permukaan, diduga merupakan jenis cumi-cumi dengan kepadatan yang relatif tinggi (Gambar 13). Kelompok ikan pelagis lainnya yang mempunyai ukuran relatif lebih besar seperti ikan tembang dan selar kuning terkonsentrasi pada lapisan permukaan sampai tengah dengan kepadatan lebih rendah dari jenis cumi-cumi. Kelompok kedua diduga merupakan jenis ikan petek, dengan kepadatan relatif tinggi di mana jumlahnya semakin bertambah seiring dengan lamanya penyinaran.

Pola agregasi ikan pada perlakuan 250 watt lampu mercury dapat dilihat pada Gambar 9. Kepadatan ikan pelagis semakin tinggi dengan lamanya penyinaran. Peningkatan jumlah ikan dengan ukuran yang semakin besar terlihat dengan semakin banyaknya ikan dengan nilai target strength yang lebih besar seiring lamanya penyinaran. Ikan tersebut didominansi jenis ikan teri yang mencapai 93\% dari total hasil tangkapan (Gambar 13). Ikan pelagis lainnya seperti cumi-cumi dan ikan tembang serta ikan demersal dengan ukuran relatif lebih besar datang 

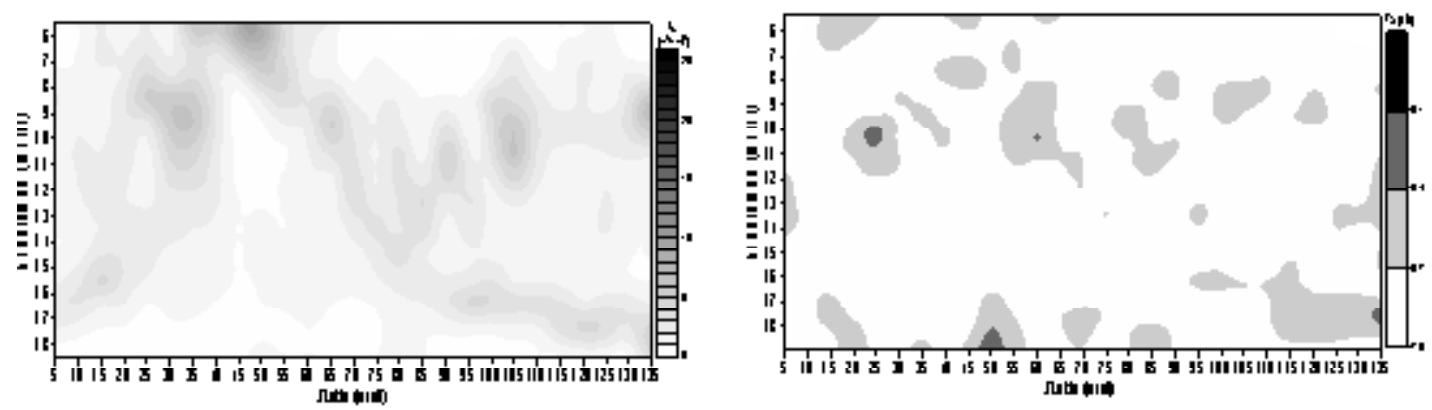

Gambar 7. Pola agregasi kepadatan (kiri) dan ukuran ikan (kanan) pada penyinaran 5 lampu petromak. Figure 7. The pattern of density (left) and fish size (right) at 5 kerosene pressured lamp ilumination.
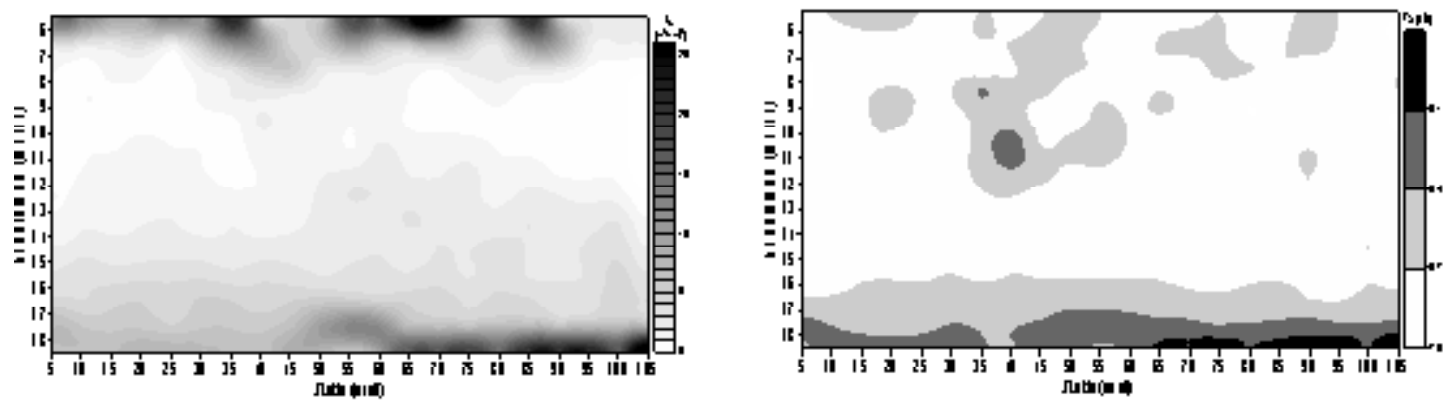

Gambar 8. Pola agregasi kepadatan (kiri) dan ukuran ikan (kanan) pada penyinaran 10 lampu petromak. Figure 8. The pattern of density (left) and fish size (right) in 10 kerosene pressured lamp ilumination.
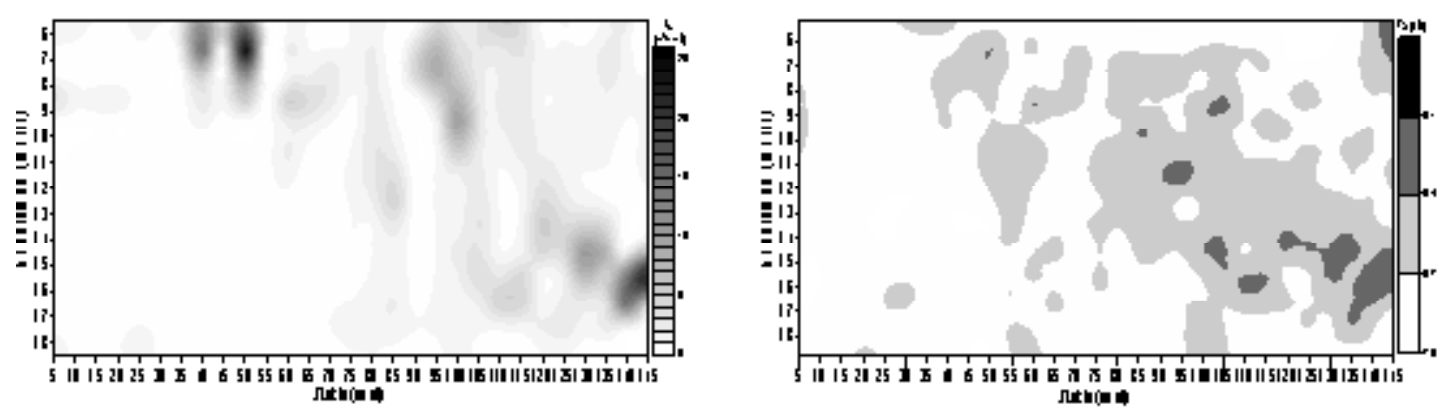

Gambar 9. Pola agregasi kepadatan (kiri) dan ukuran ikan (kanan) pada penyinaran 250 watt lampu mercury.

Figure 9. The pattern of density (left) and fish size (right) in 250 watt mercury ilumination.

pada akhir periode penyinaran. Kepadatannya lebih rendah daripada hasil perlakuan lampu petromak yang ditunjukkan dengan persentase hasil tangkapan sangat sedikit (Gambar 12).

Gambar 10 merupakan pola agregasi ikan dari perlakuan 500 watt lampu mercury yang memiliki kecenderungan sama dengan perlakuan 250 watt. Tetapi penyinaran 500 watt mempunyai rata-rata kepadatan yang lebih rendah dibanding hasil penyinaran 250 watt. Sasarannya didominansi oleh ikan teri yang mencapai $93 \%$ dari total hasil tangkapan.
Pola agregasi untuk perlakuan 1.000 watt mercury (Gambar 11), secara visual, terlihat bahwa peningkatan kepadatan ikan cenderung rendah, namun terdeteksi ikan dengan ukuran relatif lebih besar daripada ikan hasil perlakuan lainnya. Ikan-ikan tersebut merupakan ikan pelagis yang datang pada akhir periode perlakuan. Berdasarkan pada hasil tangkapan (Gambar 13), kelompok ikan ini didominansi jenis ikan tembang, selar, bentong, dan selar kuning yang berukuran lebih besar daripada ikan teri. Sulaiman (2006) mengatakan bahwa pola distribusi kawanan ikan kembung dan tembang berada di sekitar sumber pencahayaan. Hal ini yang 
menyebabkan indeks kepadatan pada perlakukan 1.000 mercury cenderung rendah, karena sasaran tidak di bawah pusat cahaya.

\section{Verifikasi Hasil Tangkapan terhadap Hasil Akustik}

Nilai terbesar rata-rata kepadatan ikan selama periode penyinaran adalah pada perlakuan 10 lampu petromak, dan kepadatan terendah pada perlakuan 1.000 watt mercury (Gambar 12). Perbandingan ratarata indeks kepadatan berdasarkan pada nilai $\mathrm{S}_{\mathrm{A}}$ untuk perlakuan 5 dan 10 petromak, 250, 500, dan 1.000 watt mercury berturut-turut 2:4:1,75:1,25:1 dalam satuan $\mathrm{m}^{2} / \mathrm{nmi}^{2}$.

Hasil pengambilan contoh menunjukkan bahwa pada perlakukan lampu petromak, nilai $\mathrm{s}_{\mathrm{A}}$ yang besar menghasilkan bobot tangkapan rendah. Hal ini dikarenakan pada perlakuan 10 petromak. Nilai $\mathrm{s}_{\mathrm{A}}$ yang besar didominansi cumi-cumi yang berada di bawah pusat cahaya, serta ikan pelagis lainnya yang berukuran lebih besar. Bobot tangkapan yang rendah dikarenakan ukuran cumi-cumi yang relatif kecil, serta ikan yang mempunyai ukuran lebih besar mempunyai gerakkan yang lebih reaktif, dan mempunyai kecepatan renang lebih tinggi daripada ikan berukuran kecil seperti ikan teri yang cenderung lebih lambat. Gerakan pindah ataupun menghindarai (escapement) yang lebih cepat tersebut mengakibatkan ikan berukuran besar tidak mudah tertangkap.

Hasil sampling 5 petromak di mana bobot tangkapan sebanding dengan nilai $\mathrm{s}_{\mathrm{A}}$, karena pada perlakuan ini sasaran didominansi ikan teri. Konsentrasi ikan teri berada di bawah sumber cahaya cenderung berputar-putar, sehingga reaksi penghindaran menjadi lambat. Pada saat intensitas dikurangi, ikan bergerak sangat aktif naik-turun di bawah sumber cahaya (Baskoro, 1999). Hal ini menyebabkan ikan teri mudah tertangkap.

Pada perlakuan lampu mercury, semakin kecil nilai $\mathrm{S}_{\mathrm{A}}$, maka bobot tangkapan semakin besar. Nilai $\mathrm{s}_{A}$ pada perlakuan 250 watt dihuni oleh sasaran dengan ukuran kecil, yaitu ikan teri, dengan konsentrasi padat, namun bobotnya kecil. Konsentrasi ikan teri pada perlakuan 500 watt lebih rendah, namun komposisi ukurannya lebih besar daripada ikan teri yang dihasilkan pada perlakuan 250 watt, sehingga bobot tangkapan pada perlakuan 500 watt lebih besar dibanding hasil 250 watt. Struktur panjang pada Gambar 13 menunjukkan hasil tangkapan ikan teri
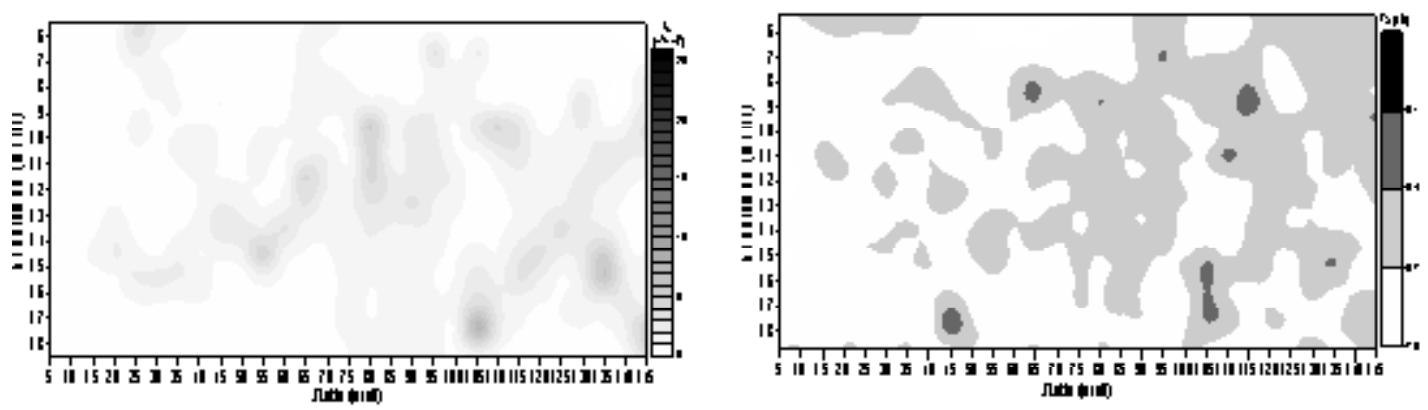

Gambar 10. Pola agregasi kepadatan (kiri) dan ukuran ikan (kanan) pada penyinaran 500 watt lampu mercury.

Figure 10. The pattern of density (left) and fish size (right) in 500 watt mercury ilumination.
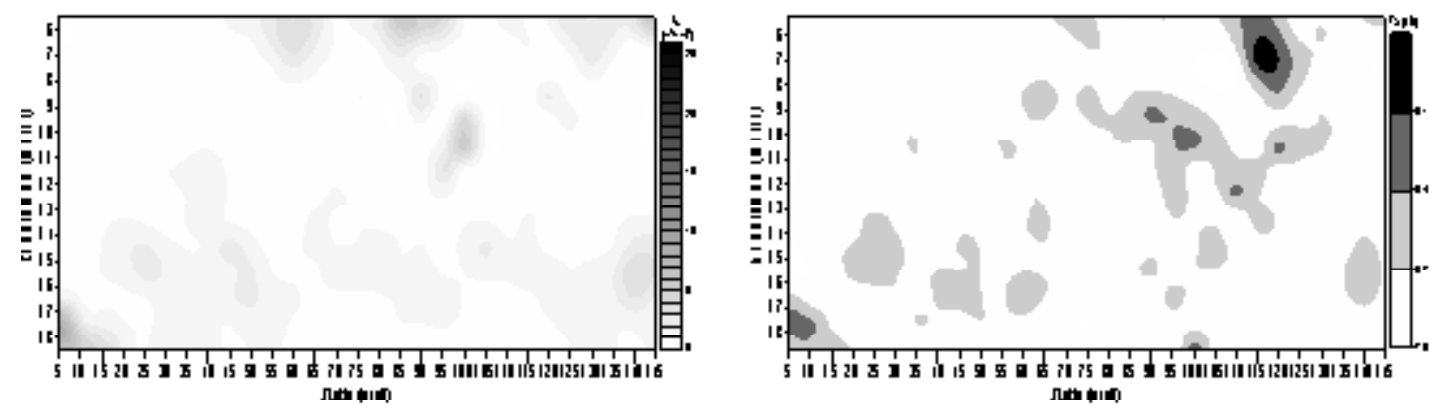

Gambar 11. Pola agregasi kepadatan (kiri) dan ukuran ikan (kanan) pada penyinaran 1.000 watt lampu mercury.

Figure 11. The pattern of density (left) and fish size (right) in 500 watt mercury ilumination. 


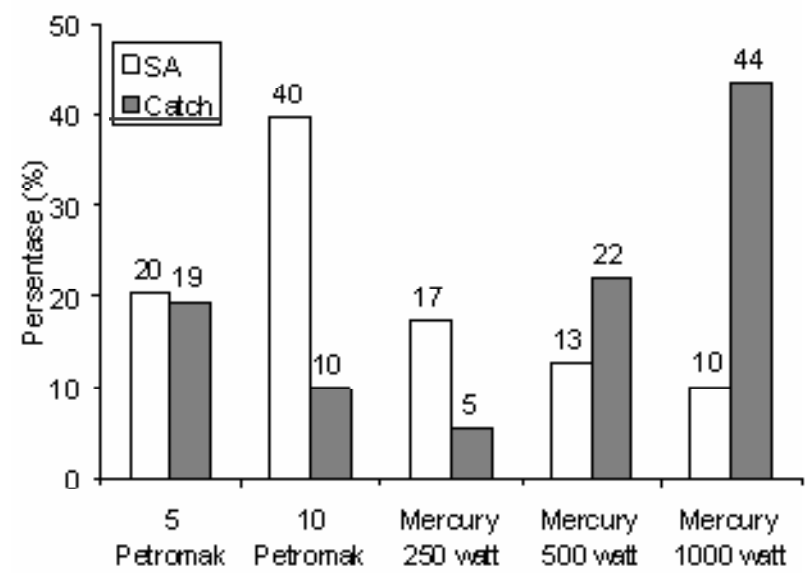

Gambar 12. Persentase nilai $\mathrm{s}_{\mathrm{A}}$ dan bobot hasil tangkapan tiap penyinaran.

Figure 12. Percentage of $s_{A}$ value and catch for each light ilumination.
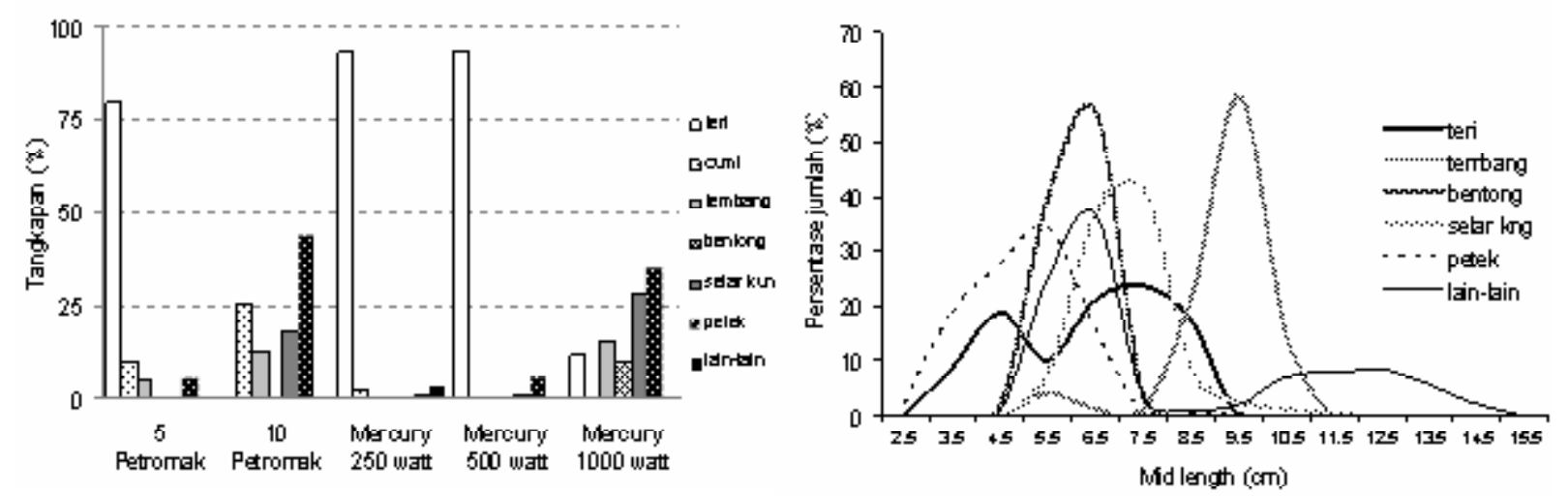

Gambar 13. Persentase bobot ikan hasil tangkapan tiap perlakuan penyinaran (kiri) dan kisaran panjang tiap jenis ikan (kanan).

Figure 13. Percentage of weight of catch for each light ilumination (left) and lenght distribution for each species (right).

mempunyai 2 kohort. Bobot hasil tangkapan terbesar diperoleh dari perlakuan 1.000 watt mercury. Perlakuan ini mampu menarik ikan yang mempunyai ukuran lebih besar dalam jumlah banyak, namun pola kepadatannya rendah dan cenderung berada di sekitar sumber cahaya.

\section{KESIMPULAN}

1. Semakin lama pencahayaan, semakin banyak ikan yang tertarik dan berkumpul di sekitar sumber cahaya. Semakin besar intensitas cahaya yang digunakan, tidak selalu menaikan jumlah ikan.

2. Ikan akan beradaptasi terhadap variasi iluminasi cahaya, sehingga selama proses pencahayaan terjadi migrasi.

3. Pengaruh intensitas cahaya yang berbeda terhadap agregasi ikan mempunyai pola kepadatan dan ukuran yang berbeda pula, sehingga nilai intensitas cahaya optimum dalam pola agregasi ikan di bagan belum dapat ditentukan.

\section{PERSANTUNAN}

Kegiatan dari hasil riset pengaruh intensitas cahaya terhadap pola pengelompokkan ikan pada alat tangkap yang menggunakan alat bantu cahaya di perairan utara Jawa, T. A. 2005, di Balai Riset Perikanan Laut-Muara Baru, Jakarta.

\section{DAFTAR PUSTAKA}

Arimoto, T. 1999. Light fishing. Paper in International Fisheries Training Centre (unpublished). JICA. Tokyo. 15 pp.

Baskoro, M. S. 1999. Capture process of the floated bamboo-flatform liftnet with light attraction (bagan). Dissertation (unpublished). Doctoral Course of Marine Science and Technology. Graduated School 
of Fisheries, Tokyo University of Fisheries. 149 pp.

Delbeek, J. C. 1986. The effect of light on the behaviour and well being of marine fish. ATOLL. 1 (2).

Levenez, J. J. \& Gerlotto. 1990. Reaction of tropical coastal pelagic species to artificial lighting and implications for the assessment of abundance by echointegration. Rapp. P. V. Reun. Cons. Int. Expl. Mer. 189: 128-134.
Nikolsky, G. V. 1963. The Ecology of Fishes. Academic Press, London.

Sulaiman, M. 2006. Pendekatan akustik dalam studi tingkah laku ikan pada proses penangkapan dengan alat bantu cahaya. Tesis (tidak dipublikasikan). Fakultas Perikanan dan IImu Kelautan. Institut Pertanian Bogor. Bogor.

Woodhead, P. M. J. 1966. The behaviour of fish relation to the light in the sea. Ecanogr. Mar. Biol. Ann. Rev. 4. Horald Barnes Edition. 337-403. 